\title{
Microbial adaptation to biodegrade toxic organic micro-pollutants in membrane bioreactor using different sludge sources
}

\author{
Jarungwit Boonnorat $^{\text {a }}$, Chart Chiemchaisri ${ }^{\mathrm{a}, *}$, Wilai Chiemchaisri ${ }^{\mathrm{a}}$, Kazuo Yamamoto ${ }^{\mathrm{b}}$ \\ a Department of Environmental Engineering, Faculty of Engineering, Kasetsart University, \\ Bangkok 10900, Thailand. \\ ${ }^{\mathrm{b}}$ Environmental Science Center, University of Tokyo, Tokyo 113, Japan
}

\begin{abstract}
Biodegradation of toxic organic micro-pollutants in municipal solid waste (MSW) leachate by membrane bioreactor (MBR) was investigated. The MBR systems were seeded with different sludge sources, one was from a pilot-scale MBR system treating MSW leachate and the other was from an activated sludge sewage treatment plant. The biodegradation of BPA, 2,6-DTBP, BHT, DEP, DBP and DEHP, DCP and BBzP, by sludge from both reactors were found improved with time. However, enhanced biodegradation of micro-pollutants was observed in MBR operated under long sludge age condition. Bacterial population analyses determined by PCR-DGGE revealed the development of phenol and phthalate degrading bacteria consortium in MBR sludge during its operation.
\end{abstract}

\section{Keywords}

Bacterial community, membrane bioreactor, microbial adaptation, micro-pollutants, PCRDGGE

* Corresponding author: Dr. Chart Chiemchaisri, Associate Professor

Tel (Fax) + 6625790730, email: fengccc@ku.ac.th 


\section{Introduction}

Phenols and phthalates are the micro-pollutants commonly found in municipal solid waste leachate. In landfill site, these chemical compounds are derived from wasted materials such as plastic, coating materials and cosmetics industries (Slack et al., 2005). Recently, several national and international organizations such as World Health Organization, United States Environmental Protection Agency, European Union International Programme on Chemical Safety (IPCS) and China National Environmental Monitoring Center classified these compounds as a priority environmental pollutants and as endocrine disrupting compounds (Huang et al., 2010). In addition, phthalates have been reported to affect biochemical process in humans including effect on reproduction, sperm damage, early onset of puberty in female, amonalies of reproductive tract, infertility, adverse outcomes of pregnancy, to neurodevelopment and allergies (Mankidy et al., 2013).

Membrane bioreactor (MBR) is reported as an effective wastewater treatment system and it is a good option for the treatment of municipal solid waste leachate that contains micropollutants or toxic organic compounds. In MBR, biological treatment takes place under unique environmental condition in which microorganisms are maintained at much higher mixed liquor suspended solids (MLSS) concentration when compared to other conventional biological treatment processes and the MBR can also improve the removal of micropollutants or toxic organic compounds via adsorption onto sludge, biodegradation and membrane filtration (Boonyaroj et al., 2012, Wijekoon et al., 2013). Nevertheless, the removals of micro-pollutants depends on their molecular properties (Tadkaew et al., 2011) and environmental conditions such as $\mathrm{pH}$ and temperature (Tadkaew et al., 2010, Hai et al., 2011). To improve the biodegradation of some recalcitrant organic compounds, MBR system provides an opportunity to operate under long sludge age condition through an operation without sludge wastage. This environmental condition makes the system capable of cultivating slow growing microorganisms, resulting in highly diverse bacterial consortium in the system and thus enhancing the biodegradation of those compounds. Even though, solid retention time (SRT) has been considered as an important operating criteria for the removal of micro-pollutants, its effect on the microbial adaptation and population change during the treatment of wastewater containing toxic organic micro-pollutants in long term is not well known. Therefore, this research was carried out to study effect of sludge source to 
biodegrade those compounds in the MBR systems. Batch experiments were also carried out using microbial sludge obtained from laboratory scale MBR of this study to determine the maximum micro-pollutants biodegradation capacities. Microbial population shift in response to the performance of MBR systems was studied using polymerase chain reaction denaturing gradient gel electrophoresis (PCR-DGGE) technique during long term operation of the MBR systems.

\section{Methods}

\subsection{Membrane bioreactor set-up and operation}

The experiment was conducted with two laboratory scale MBR units made of acrylic plastic with $0.30 \mathrm{~m}$ in width, $0.10 \mathrm{~m}$ in length $\mathrm{x} 0.50 \mathrm{~m}$ height $(0.30 \mathrm{~m}$ water depth) dimension and working volume of 9 L. A polyvinylidene difluoride (PVDF) hollow-fiber microfiltration (MF) membrane module (Sterapore SADF0790M, Mitsubishi Rayon, Japan) with nominal pore size of $0.4 \mu \mathrm{m}$ and effective membrane surface area of $0.07 \mathrm{~m}^{2}$ was used for solid-liquid separation in the reactor. Membrane permeate was intermittently withdrawn by suction pumps in a 5-minute on/1-minute off cycle to maintain constant hydraulic retention time (HRT) in the MBR at 24 hours. The reactor was operated under room temperature condition $\left(25-30^{\circ} \mathrm{C}\right)$ where $\mathrm{pH}$ of mixed liquor was 7.0-8.0 and dissolved oxygen (DO) in the reactor was maintained at $5-6 \mathrm{mg} / \mathrm{l}$.

Leachate used in the experiment was prepared by mixing fresh and stabilized leachate obtained from a municipal solid waste landfill site in Thailand and that biochemical oxygen demand (BOD) and chemical oxygen demand (COD) were maintained constant at about 3,000 and $6,500 \mathrm{mg} / \mathrm{l}$. The concentrations of toxic organic micro-pollutants including bisphenol A (BPA), 2,6-di-tert-butylphenol (2,6-DTBP), 2,6-di-tert-4-methyl-butylphenol (BHT), ethyl phthalate (DEP), butyl phthalate (DBP), bis (2-ethylhexyl) phthalate (DEHP), 2-chlorophenol (DCP) and benzyl butyl phthalate (BBzP) were adjusted equally at 1,000 $\mu \mathrm{g} / 1$ and supplied into the MBR systems. The characteristics of leachate used in this study are shown in Table 1.

\section{Insert Table 1}


In order to investigate the removals of toxic organic micro-pollutants in different sludge sources of MBR systems, two sets of MBR system were operated in parallel. The first reactor (MBR 1) was initially seeded with microbial sludge obtained from a pilot-scale MBR installed at a solid waste disposal site where leachate was obtained. The pilot-scale MBR had been operated continuously for about 2 years without sludge wastage condition and this sludge is named 'acclimatized sludge'. After initial seeding of sludge, the operation of laboratory sale MBR 1 was also performed under no sludge wastage condition (for maintain it source condition) except for sampling purpose (approx. $100 \mathrm{ml}$ every 7 days) so actual sludge age in this reactor was increasing with the operation days until the end of experiment (day 550). The other reactor (MBR 2) utilized seed sludge from an activated sludge sewage treatment plant which is operating at a SRT of 15 days (non-acclimatized sludge). After the start-up, this reactor (MBR 2) was operated at a constant SRT of 15 days which for maintain it source condition by wasting excess sludge daily from the reactor. These experimental setup was employed to ensure that microorganisms presented in the MBR systems had been originally cultivated at the same HRT $(24 \mathrm{~h})$ but different SRT (infinite and 15 days respectively) as they are operated in this study.

All water quality parameters in the influent (leachate) and treated water (membrane permeate) were analyzed every 7 days. The analyzed parameters included pH, BOD, COD, ammonia nitrogen, total kjeldahl nitrogen (TKN), total nitrogen (TN) and total phosphorus (TP). The biomass concentrations in the reactor were determined in term of MLSS and mixed liquor volatile suspended solids (MLVSS). The removal of toxic organic micro-pollutants during the reactor operation was studied by analyzing their concentrations in influent and effluent and adsorbed amount on biomass (sludge) samples every 7 days over the entire experimental period (550 days).

\subsection{Determination of micro-pollutant biodegradation in batch experiments}

Batch experiments were performed to investigate the maximum removal capacities of toxic organic micro-pollutants by MBR sludge in each reactor at the beginning (day 0) and towards the end of the experiment (day 519). In order to differentiate the removals of studied compounds via adsorption and biodegradation mechanisms, batch experiments were 
performed using active (untreated) and inactivated MBR sludge following the procedures described in our previous study (Boonyaroj et al., 2012). Sludge was tested for their capacity in removing eight compounds presented in municipal solid waste leachate. Batch experiments were performed under aeration at DO level of $4-5 \mathrm{mg} / \mathrm{l}$. In the batch experiment, sludge samples having MLSS of $3.0 \mathrm{~g} / 1$ were spiked with BPA, 2,6-DTBP, BHT, DEP, DBP, DEHP, $\mathrm{DCP}$ and BBzP at an initial concentration of $3,000 \mu \mathrm{g} / 1$ and their concentrations were determined every 2 hours during a $24 \mathrm{~h}$ experiment which was equal to the HRT of the MBR (reactor experiment). The initial concentration of those compounds was selected based on our preliminary experiments to ensure that the tested compounds remained after 24 hours during batch experiment so that maximum removal capacities by sludge in batch experiment could be obtained. These batch experiments were all conducted in triplicate.

For sludge inactivation, the MBR sludge was repeatedly autoclaved at $121^{\circ} \mathrm{C}$ for 15 minutes three times in order to completely terminate microbial activities. The removals of toxic organic micro-pollutants by active sludge were due to both adsorption and biodegradation mechanisms whereas the removal by inactivated sludge was only due to adsorption of compounds onto sludge particles. Maximum biodegradation capacities of micro-pollutants by sludge were expressed in terms of the percentages of micro-pollutants being removed via biodegradation during 24 hours of batch experiment. The removals of micro-pollutants via biodegradation was derived from the amount of micro-pollutants removed by active sludge was subtracted by the amount of micro-pollutants removed by inactivated sludge.

The percentage of micro-pollutants biodegraded during batch experiment and first order rate constants for the removals of each micro-pollutant in batch experiment by MBR 1 and MBR 2 sludge were compared at day 0 and day 519 to investigate the effect of sludge source on the micro-pollutant biodegradation capacities of MBR sludge.

\subsection{Water qualities and toxic organic micro-pollutants analyses}

Chemical characteristics of leachate and treated water were regularly monitored using the analytical procedures described in Standard Methods for the Examination of Water and Wastewater (APHA, 2005). 
The concentrations of toxic organic micro-pollutants in water sample were determined by solid phase extractions (SPE). To determine their concentrations in soluble form, the water samples obtained after separation of suspended solids by $\mathrm{GF} / \mathrm{C}$ filtration were used. The Vertipak $^{\mathrm{TM}}-\mathrm{C} 18$ tubes or SPE tubes were used for extraction of toxic organic compounds. Firstly, SPE tubes were clean with $10 \mathrm{ml}$ dichloromethane: methanol $(1: 9 \mathrm{v} / \mathrm{v})$, followed by $10 \mathrm{ml}$ pure water and $50 \mathrm{ml}$ filtrated water sample. The SPE tubes were left for drying with clean air and eluted with $5 \mathrm{ml}$ of dichloromethane: methanol $(1: 9 \mathrm{v} / \mathrm{v})$. The solvent volume of soluble extracted sample was reduced to $2 \mathrm{ml}$ by nitrogen evaporator and concentrator (ChanoVap, Amani, Thailand). To determine the micro-pollutants in solid bounded form, sludge samples obtained on $\mathrm{GF} / \mathrm{C}$ filter were added to $20 \mathrm{ml}$ dichloromethane: methanol (1:9 $\mathrm{v} / \mathrm{v})$ and mixed for 1 hour followed by sonication for $15 \mathrm{~min}$. The solvent samples $(5 \mathrm{ml})$ were then pumped into C18-SPE column and the collected samples were concentrated to $2 \mathrm{ml}$ by evaporator and concentrator.

Gas chromatography with mass spectrometry (Shimadzu, GCMS-QP2010 plus) was used for determination of the concentrations of toxic organic micro-pollutants. The device was equipped with a $30 \mathrm{~m}$ RTX-35MS capillary, $0.25 \mathrm{~mm}$ I.D. with thickness of $0.5 \mu \mathrm{m}$. Helium was used as carrier gas. Sample $1 \mu \mathrm{l}$ was injected automatically. Three different GC-MS programs were set for the analyses of eight toxic organic micro-pollutants targeted in this study. The first program for BPA analysis having the operating condition as follows oven temperature was set at $60^{\circ} \mathrm{C}$ and then increased to $150^{\circ} \mathrm{C}$ at a rate of $7^{\circ} \mathrm{C} / \mathrm{min}$ with holding time of 5 minutes. The instrument condition was set at electron impact of $70 \mathrm{eV}$, ion source temperature of $200^{\circ} \mathrm{C}$ and interface temperature of $250^{\circ} \mathrm{C}$. The second program for BHT, 2,6DTBP and DCP analyses was set at oven temperature of $60^{\circ} \mathrm{C}$, increased to $100^{\circ} \mathrm{C}$ with holding time of 2 minutes and then further increased to $150^{\circ} \mathrm{C}$ at a rate of $3.5^{\circ} \mathrm{C} /$ minute with holding time of 5 minutes. The instrument condition was set at electron impact at $70 \mathrm{eV}$, ion source temperature at $150^{\circ} \mathrm{C}$ and interface temperature at $250^{\circ} \mathrm{C}$. The third program for DEP, DBP, DEHP and BBzP analyses was set at oven temperature of $60^{\circ} \mathrm{C}$, increased to $100^{\circ} \mathrm{C}$ with holding time of 5 minutes, then increased from $100^{\circ} \mathrm{C}$ to $150^{\circ} \mathrm{C}$ at a rate of $10^{\circ} \mathrm{C} /$ minute and holding time of 5 minutes, followed by an increase from $150^{\circ} \mathrm{C}$ to $195^{\circ} \mathrm{C}$ at a rate of $3^{\circ} \mathrm{C} /$ minute with holding time of 5 minutes, increased from $195^{\circ} \mathrm{C}$ to $205^{\circ} \mathrm{C}$ at a rate of $1{ }^{\circ} \mathrm{C} /$ minute with holding time of 10 minutes and finally increased from $205^{\circ} \mathrm{C}$ to $250^{\circ} \mathrm{C}$ at a rate of $10^{\circ} \mathrm{C} /$ minute with holding time of 15 minutes. The instrument condition was set at 
electron impact of $70 \mathrm{eV}$, ion source temperature of $200^{\circ} \mathrm{C}$ and interface temperature of $270^{\circ} \mathrm{C}$. The peak chromatogram were referenced with Wiley library MS-spectra. The lower detection limit for the analyses was $1.0 \mu \mathrm{g} / \mathrm{l}$ and the analyzed results were compared with blank samples using MilliQ water (molecular grade pure water). The same analytical procedures were applied to internal standards of known concentrations $(3,000 \mu \mathrm{g} / \mathrm{l})$ of all eight toxic organic micro-pollutants. The recovery percentages obtained from using internal standards were varied between $86.5 \%$ and $97.2 \%$.

\subsection{Bacteria community analyses}

PCR-DGGE technique was used for the identification of major bacteria species and their population changes during the operation of MBR. Mixed liquor sludge samples are collected from both reactors at day 0 (start-up), day 104, day 207, day 310, day 412 and day 519 respectively. Collected samples were refrigerated at $-80^{\circ} \mathrm{C}$ until analysis. Genomic DNAs from bacteria are extracted by the PrepEase ${ }^{\circledR}$ Tissue and Cell DNA Spinkit (USB Corporation, USA) in accordance with the manufacturer's specifications. This PCR was performed using 338GC-F (5'-ACTCCTACGGGAGGCAGC-3') and 518R (5'-ATTACCGCGGCTGCTGG-

$\left.3^{\prime}\right)$ as universal bacteria primer for bacteria community screening in samples. The combination of these primer had generated a PCR fragment about 180-190 bp which was suitable for subsequent DGGE analysis.

The PCR amplification of genes in this study was performed according to the following condition; $50 \mu 1$ of PCR reaction contained $1 \mu \mathrm{l}$ of genomic DNA template, $1 \mathrm{x}$ PCR buffer, 3 $\mathrm{mM} \mathrm{MgCl} 2,200 \mu \mathrm{M}$ deoxynucleoside triphosphates (dNTPs), 10 pmol of each primer, and 1 U of Taq DNA polymerase (Qiagen, Germany). The PCR was conducted in a Perkin-Elmer GeneAmp PCR System 9700 (Applied Biosystem, USA). The thermal program was set as followed; initial denaturation at $95^{\circ} \mathrm{C}$ for 10 minutes, followed by 30 cycles of denaturation at $95^{\circ} \mathrm{C}$ for 50 seconds, annealing at $60^{\circ} \mathrm{C}$ for 30 seconds and extension at $72^{\circ} \mathrm{C}$ for 50 seconds. Finally, the extension step was performed at $72^{\circ} \mathrm{C}$ for 7 minutes. The size and amount of PCR products were visualized on a $1.2 \%(\mathrm{w} / \mathrm{v})$ agarose gel electrophoresis staining with ethidium bromide and estimated for DNA quantity using a NanoDrop 1000 spectrophotometer (thermo scientific, USA). 
DGGE analyses of 16s DNA amplified PCR products were using the DGGE-2000 system apparatus (CBS Scientific Company, Del Mar, CA). They were performed with different ranges of denaturants for PCR products amplification. The polyacrylamide gel concentration of MBR1 samples were applied on $9 \%(\mathrm{w} / \mathrm{v})$ polyacrylamide gel in range of $30-70 \%$ denaturing gel gradient. The MBR 2 samples were applied on $8 \%(\mathrm{w} / \mathrm{v})$ polyacrylamide gels with a ranged of $40-60 \%$ denaturing gel gradient. The eighty percent of denaturant is corresponded to $5.6 \mathrm{M}$ of urea and $32 \%(\mathrm{v} / \mathrm{v})$ formamide in 1x TAE. Electrophoresis of both DGGE analysis was performed for $16 \mathrm{~h}$ at a constant voltage of $80 \mathrm{~V}$. The temperature was set at a constant temperature of $60^{\circ} \mathrm{C}$. The polyacrylamide gel was stained with SYBR Gold nucleic acid gel stain (Invitrogen, USA) for $30 \mathrm{~min}$ before visualized on a UV transillumination and photographs were capture using Biovision CN 1000/26 M (Vilber Lourmat, France). DGGE profiles were observed from obtained band light intensities at different locations. The selected bands were excised from the polyacrylamide gel and re-suspended in $20 \mu \mathrm{l}$ of MilliQ water and stored overnight at $4^{\circ} \mathrm{C}$. The eluted DNA were used as the templates for re-amplification. The DNA sequences were manually identified using the online BLAST software on the NCBI website (http://www.ncbi.nlm.nih.gov/) and aligned with the GenBank reference.

\section{Results and discussion}

\subsection{Treatment performance and removals of toxic organic micro-pollutants of different} sludge source in MBR under long term operation

In this experiment, we continuously operated the membrane bioreactors (MBR 1 and MBR 2) for a period of 550 days and monitored the qualities of influent/effluent water and toxic organic micro-pollutants concentrations. The influent and effluent water qualities in Table 1 from both MBR systems. The average BOD, COD, and TN concentrations in fed leachate were 3074, 6469 and $205 \mathrm{mg} / \mathrm{l}$. After the treatment, effluent from MBR1 contained average $\mathrm{BOD}, \mathrm{COD}$ and TN concentrations of 5.0,131 and $30.6 \mathrm{mg} / 1$ corresponding to the removals of $99.8 \%, 98.0 \%$ and $85.1 \%$ respectively. In MBR 2, the removals of BOD, COD and TN were $99.5 \%, 96.4 \%$ and $83.7 \%$ yielding average effluent concentrations of 16, 234 and 33.5 $\mathrm{mg} / 1$ respectively. Meanwhile, the removals of TP were equal $(84.6 \%)$ in both reactors. For 
this study, the removals of nutrients $(\mathrm{N}, \mathrm{P})$ were mainly due to their uptake for microbial growth as both reactors were operated under aerobic condition.

Figure 1 shows the time courses of influent and effluent COD and MLSS concentrations in MBR 1 and MBR 2. During the start-up period (day 0 - day110), MLSS concentrations in MBR 1 were gradually increasing from about $5 \mathrm{~g} / 1$ to $16 \mathrm{~g} / 1$ in response to organic loading to the reactor as it was operated under no sludge wastage condition. Then, MLSS concentrations reached a plateau and became stable between 16 - $18 \mathrm{~g} / \mathrm{l}$ during the steady operation period (day 110 - day 550). For MBR 2, MLSS increased to about $12 \mathrm{~g} / 1$ during start-up period and maintained at $10-14 \mathrm{~g} / 1$ during steady operation. MLSS concentrations in MBR 2 operated at SRT of 15 days were found to be about $25 \%$ lower than those observed in MBR 1 .

\section{Insert Figure 1}

The influent, in reactor (sludge) and effluent concentrations of toxic organic micro-pollutants in MBR system during steady operation (day 110 - 550) are shown in Figure 2. The influent concentrations of all compounds were varied at about $1,000 \mu \mathrm{g} / 1$ and then after treatment the effluent concentrations were found less than $10 \mu \mathrm{g} / 1$ - only 2,6 DTBP, BHT, DEP, DBP, DEHP and BBzP were observed at a low noticeable level. However, from this treatment, it was shown that most of those compounds found at early stage of operation were disappeared from the effluent after 400 days of operation. For BPA, 2,6 DTBP, DEP and DCP, the removals were mainly contributed from their biodegradation as they were not accumulating onto sludge solids. For BHT, DBP, DEHP and BBzP, their accumulations onto sludge solids were observed, but among them, only DEHP was found at higher level.

\section{Insert Figure 2}

For MBR 2, as shown in Figure 3, the concentrations level of all toxic organic micropollutants were found below $10 \mu \mathrm{g} / 1$ - except those of DEHP which were between 10 - 20 $\mu \mathrm{g} / \mathrm{l}$. In most cases, the effluent concentrations were regularly detected during the whole experimental period. Accumulation onto sludge solids were observed for the same compounds as MBR 1 but they were detected at lower level. The concentrations detected on 
sludge solids also leveled off during most of the operation period. Hence, it was suggesting that there was a balance between inflow of toxic organic micro-pollutants, biodegradation in the reactor and their outflow via effluent and sludge discharges.

\section{Insert Figure 3}

Table 2 shows average concentrations of toxic organic micro-pollutants in the influent, MLSS and effluent of MBR 1 and MBR 2. The concentrations in waste sludge was also considered in MBR 2. Average removal efficiencies of toxic organic micro-pollutants in MBR 1 were $99.8 \%$ for BPA, 99.9\% for 2,6-DTBP, 99.3\% for BHT, $99.8 \%$ for DCP, $99.7 \%$ for DEP, $99.5 \%$ for DBP, $99.1 \%$ for DEHP and 99.4\% for BBzP. In MBR 2, the removal efficiencies were $99.7 \%$ for BPA, $98.8 \%$ for 2,6 -DTBP, $99.0 \%$ for BHT, $99.4 \%$ for DCP, 99.5\% for DEP, $99.5 \%$ for DBP, $98.1 \%$ for DEHP and $99.1 \%$ for BBzP. Among them, the removal of DEHP was found lowest and most of their removals were due to adsorption onto sludge solids. In MBR 1, 75.7\% of DEHP were adsorbed onto MLSS which was kept inside the reactor. In MBR 2, 26.0\% of DEHP was kept inside the reactor and 29.2\% were discharge together with excess sludge.

\section{Insert Table 2}

It was found that most of toxic organic micro-pollutants, except DEHP, were mainly removed by biodegradation mechanism as the contribution from adsorption onto sludge solids in their removal was less than $10 \%$. One of the key factors affecting their removals was their chemical properties. The compounds with higher octanol-water partition coefficient $\left(\mathrm{K}_{\mathrm{ow}}\right)$ or hydrophobic in nature tend to adsorb onto sludge solids and accumulated in reactors or discharge with excess sludge whereas other compounds with lower $\mathrm{K}_{\mathrm{ow}}$ were removed in aqueous by biodegradation. Considering the properties of micro-pollutants other than DEHP in this study, their $\log \mathrm{K}_{\mathrm{ow}}$ values were ranged from 3.32 to 5.10 (Table 3). Meanwhile, DEHP which is relatively hydrophobic compound $\left(\log \mathrm{K}_{\mathrm{ow}}=7.50\right)$ and mainly found associated with sludge solids was removed through adsorption in the MBR. In general for compounds with $\log \mathrm{K}_{\mathrm{ow}}<2.5$, the adsorption to activated sludge was not contribute significantly to removal of the organic micro-pollutants via excess sludge withdrawal. 
Between $\log \mathrm{K}_{\mathrm{ow}}$ of 2.5 to 4 , moderate adsorption is expected whereas values higher than 4.0 are synonym to high adsorption potential.

\section{Insert Table 3}

\subsection{Biodegradation of toxic organic micro-pollutants by MBR sludge}

The biodegradation of toxic organic micro-pollutants was studied in batch experiments using MBR sludge at day 0 and day 519 of operation. Table 3 shows percentages of toxic organic micro-pollutant removals via biodegradation and their first order removal rate constant in MBR 1 and MBR 2. On day 0, MBR 1 sludge had high biodegradation efficiencies in range between $79 \%$ and $87 \%$. The highest removals were from those compounds having lower log $\mathrm{K}_{\mathrm{ow}}$ values whereas the lowest removal was BBzP. In case of MBR 2 sludge, the biodegradation percentages were 61-71\% - lower values were those of DEHP and BBzP and highest value was DCP. Significant higher biodegradation percentages were found in case of MBR 1 sludge which obtained from pilot-scale MBR system operated at solid waste disposal site. The difference in biodegradation percentages between both sludge was mainly due to acclimatization of sludge to leachate characteristics and toxic organic micro-pollutants.

From the batch experiment, it was found that micro-pollutant were degraded well by sludge of two reactors. In comparison, the batch experiment of acclimatized-sludge from MBR 1 or sludge that were familiar with toxic compounds for over 500 days performed better with higher removal efficiencies than those of non-acclimatized sludge from MBR 2. However, the biodegradation of all type of sludge was found improved with time and they were highest at day 519. During the whole operation period, the biodegradation removals of BPA, 2,6DTBP, BHT, DCP, DEP, DBP, DEHP and BBzP in MBR 1 were adaptively improved by 8$12 \%$. For non-acclimatized sludge from MBR 2, the removal efficiencies was improved by $5-$ $17 \%$.

The rates of micro-pollutants removals were found to follow first-order kinetic expression as follow.

$\ln \left(\mathrm{C}_{\mathrm{t}} / \mathrm{C}_{0}\right)=-k t$ 
where $C_{o}(\mu \mathrm{g} / 1)$ and $C_{t}(\mu \mathrm{g} / 1)$ were the concentrations of toxic organic micro-pollutants in aqueous solution at initial time and time $t$ (hours or $\mathrm{h}$ ). $k\left(\mathrm{~h}^{-1}\right)$ was first order rate constant for the removal of the micro-pollutants.

Considering the rate constant $(\mathrm{k})$ of the micro-pollutant from the batch experiment mentioned above, it was found that removal rate of each toxic organic micro-pollutant by biodegradation mechanism was adaptively improved. The rate constant $(\mathrm{k})$ of day 0 of acclimatized sludge from MBR 1 was ranged between 0.187-0.289 $\mathrm{h}^{-1}$ and by day 519 was improved to 0.205$0.362 \mathrm{~h}^{-1}$. As well as the batch experiment of non-acclimatized sludge from MBR 2, the rate constant $(\mathrm{k})$ was ranged between $0.124-0.216 \mathrm{~h}^{-1}$ and improved to $0.171-0.295 \mathrm{~h}^{-1}$ by day 519.

From this batch experiment, the key factors that affected the removal efficiencies of toxic organic micro-pollutants were described as follows:

(1) Hydrophobicity: This was determined by the ' $\log \mathrm{K}_{\mathrm{ow}}$ ' of those toxic organic micropollutants and with low $\log \mathrm{K}_{\mathrm{ow}}$ were degraded well with biodegradation such as BPA and DCP

(2) Molecular weight. From our experiment, those compounds with low molecular weight were degraded well and better than those compounds with high molecular weight. For example, DEHP and BBzP which have high molecular weight and were degraded in lower rate with biodegradation compared to other compounds.

(3) Chemical structure e.g. branch structure or aromatic ring. From the experiment, it was shown that $\mathrm{DEHP}$ and $\mathrm{BBzP}$ with long branch chain and many aromatic rings were deranged later when compared to other compounds. Tadkaew et al. (2011) reported that functional group in chemical structure was one of the factors that affected the degradation rate. In our study, function group of all compounds contained electron donating group (EDG) which were considered to be easily degraded in the MBR system. The EDG group were including primary amine group, hydroxy1 group, ether group, carbonyl group and alky1 group. 


\subsection{Bacteria community in MBR sludge}

The PCR-DGGE technique was used to determine bacteria community in MBR sludge and their changes along the reactor operation. On day 0 , nine bacterial strains were found in acclimatized sludge (MBR 1) including Pseudomonas sp. UW4, Pseudomonas fluorescens Pf0-1, Pseudomonas syringae B728a, Burkholderia sp. CCGE1002, Nitrosomonas sp. AL212, Enterobacter sp. OM1, Burkholderia multivorans ATCC17616, Sphingobacterium sp. 21, Rhodopseudomonas palustris CGA009. Meanwhile, seed sludge from nonacclimatized sludge (MBR 2) was found to contain seven bacterial strains including Nitrobacter hambergensis X14, Pseudomonas syringae B728a, Pseudomonas fluorescens Pf0-1, Methylobacillus flagellatus KT, Agrobacterium fabrum str C58, Rhodospirillium centenum SW, Maribacter sp. HTCC2170. Many researchers had suggested the presence of phenolic and phthalate degrading bacteria in acclimatized sludge on day 0 (Figure 4) and there was fewer effective bacteria to biodegrade such compounds in non-acclimatized sludge (Figure 5).

\section{Insert Figure 4}

\section{Insert Figure 5}

Along the operation of MBR 1 over 550 days, most of the bacteria population originally presented in seeded sludge was maintained within the system as well as those newly detected species along the operation. The classification of bacteria community included 3 phylums, i.e. Bacteriodetes, Proteobacteria and Firmicutes. The Bacteroidetes included 2 species, i.e. Flavabacterium psychrophilum JIP02/86, Sphingomonas sp. 21. Proteobacteria found in the reactor was identified in three classes, i.e. $\beta$ - Proteobacteria, $\alpha$ - Proteobacteria and $\gamma$ Proteobacteria including 14 species as follows; Burkholderia sp. CCGE1002, Burkholderia multivorans ATCC17616, Ralstonia pickettii 12J, Nitrosomonas sp. AL212, Dechloromonas aromatica RCB, Enterobacter sp. OM1, Klebsiella oxytoca KCTC1686, Klebsiella pneumonia subsp. pneumonia MGH78578, Pseudomonas sp. UW4, Pseudomonas fluorescens Pf0-1, Pseudomonas syringae B728a, Xanthomonas oryzae pv. oryzae KACC10331, Rhodopseudomonas palustris CGA009 and Agrobacterium sp. H13-3. For phylum Firmicutes, Bacillus subtilis No.66 was found (Figure 4). 
The DGGE profile revealed development of new bacteria population in MBR 1 over long term operation. Dechloromonas aromatica RCB that could biodegrade organic compounds with aromatic ring structure was detected on day 207. Meanwhile, Bacillus subtilis No.66 which had been reported on their phthalate degradation ability was first detected on day 310 together with Klebsilla pneumoniae subsp. MGH78578 which could degrade phenols as well as phthalates. On the later day, Xantomonas oryzae pv. oryzae KACC10331 which utilized phenols was found on day 412 and day 519. Agrobacterium sp. H13-3, Klebsiella oxytoca KCTC1686, Ralstonia pickettii 12J were found on day 519 which all of these species had been reported on their abilities to biodegrade toxic organic micro-pollutants.

The changes in bacteria community in MBR 2 are shown in Figure 5. There were 2 phylums and 19 strains. Phylum Bacteroidetes included Maribacter sp. HTCC2170 and Sphingomonas wittichii RW1. Phylum Proteobacteria were identified in 3 classes, i.e. $\beta$ - Proteobacteria, $\alpha$ Proteobacteria and $\gamma$ - Proteobacteria including Burlkholderia sp. CCGE1002, Nitrosomonas eutropha C91, Nitrosomonas sp. Is79A3, Methylobacillus flagellatus KT, Methylovorus glucosetrophus SIP3-4, Klebsiella pneumonia subsp. pneumonia MGH78578, Pectobacterium wasabiae WPP163, Pseudomonas sp. UW4, Pseudomonas fluorescens Pf0-1, Pseudomonas syringae B728a, Pseudomonas putida KT2440, Xanthomonas albilineans GPE PC73, Rhodopseudomonas palustris CGA009, Nitrobacter hambergensis X14, Agrobacterium fabrum str C58, Rhodospirillium centenum SW and Rhodomicrobium vannielii ATCC17100.

For MBR 2 bacterial population changes along the operation were also observed (Figure 5). Some bacteria which was originally presented in seeded sludge were found disappeared at some stage of operation. Pseudomonas syringae B728a, Pseudomonas fluorescens Pf0-1 disappeared after 104 days of operation whereas Pseudomonas putida KT2440 was later found on day 310-412 and disappeared on day 519. Rhodopseudomonas palustris CGA009 which is capable of degrading phenolic compounds was found on day 0 to day 412 but later disappeared on 519 days.

The DGGE profile helped confirmed that micro-pollutants removal efficiency was depending on characteristics of bacteria community in each sludge. The acclimatized sludge in MBR 1 
were degraded well with bacteria that were familiar with toxic organic micro-pollutants. It contained a lot of bacteria species that available in nature to help degrade phenol and phthalate. However, bacteria species in both MBR 1 and MBR 2 had adaptively improved during reactor operation by time after they become familiar with those micro-pollutants.

In addition, phenol and phthalate compounds contain aromatic ring in their chemical structure. The biodegradation of phenols and phthalates have 'catechol' and 'protocatechuate' as intermediate compounds. It was reported that enzyme responsible for phenol degradation was 'phenol hydroxylase' (Chen et al., 2003). This enzyme is responsible for converting phenol to catechol, and the reaction is an initial and rate-limiting step of phenol degradation. Proteobacteria, especially the genus Pseudomonas including Pseudomonas sp., Pseudomonas putida, Pseudomonas fluorescens, Pseudomonas syringae has been reported to produce phenol hydroxylase (Zhang et al., 2004). The catechol is an intermediate compounds in phenol degradation could be degraded by 'catechol dioxygenase' enzyme that produced from Acinetobacter, Klebsiella, Bacillus, Ralstonia and Pseudomonas (Kalogeris et al., 2006; Jiang et al., 2004).

For phthalate degradation, enzyme responsible for hydrolysis of ester bond is 'esterase' and Bacillus subtilis (Peerzada et al., 2006), Pseudomonas fluorescens and Pseudomonas putida were reported to produce this enzyme (Rehdorf et al., 2012; Shaw et al., 2006). In addition, 'phthalate dioxygenase' is an enzyme responsible for key step in phthalate degradation (Batie et al., 1987; Stanislauskiene et al., 2011). The degradation of phthalates by phthalate dioxygenase, oxygen is the main importance factor of degradation pathway under aerobic condition and there are some reports mentioning bacterial strains capable to produce phthalate dioxygenase as Burkholderia sp., Burkholderia multivorans, Ralstonia picketti and Pseudomonas putida.

Moreover, 'protocatechuate dioxygenase' is also the key enzyme for breaking aromatic ring of protocatechuate and Pseudomonas sp. has been reported to produce protocatechuate dioxygenase (Yun et al., 2004). The products of phenols and phthalates degradation include pyruvate, oxaloacetate, succinate and acetyl Co A (Zhang et al., 2004; Vamsee et al., 2008) which are completely transformed in the 'krebs cycle'. 


\section{Conclusions}

Toxic organic micro-pollutants removals in MBR seeded with acclimatized sludge from leachate treatment system and non-acclimatized sludge from activated sludge sewage treatment plant were investigated. The removals of BPA, 2,6-DTBP, BHT, DEP, DBP and DEHP, DCP and BBzP, in both reactors were higher than $98 \%$ but their biodegradation in MBR seeded with acclimatized sludge. The biodegradation capacities of sludge were also improved by time. PCR-DGGE analyses revealed development of phenolic and phthalate degrading bacteria along with improved micro-pollutants biodegradation. The biodegradation of micro-pollutants by acclimatized and non-acclimatized sludge was improved with time because of microbial adaptation in the systems.

\section{Acknowledgement}

We appreciate the financial support for this study from Japan Science and Technology Agency (JST) and Japan International Cooperation Agency (JICA) through Research and Development for Water Reuse Technology in Tropical Regions (WaterIntro) project. We would like to thanks Dr. Somkiet Techkarnjanaruk, Senior Researcher of Excellent Center of Waste Utilization and Management (ECoWaste), King Mongkut's University of Technology Thonburi (KMUTT) and National Center for Genetics Engineering and Biotechnology of National Science and Technology Development Agency (NSTDA) and Miss Nimaradee Boonapatcharoen, researcher of Excellence Center of Waste Utilization and Management (ECoWaste), King Mongkut's University of Technology Thonburi (KMUTT) for their support on molecular biology analyses.

\section{References}

1. APHA, 2005. Standard Methods for the Examination of Water and Wastewater, $21^{\text {st }}$ ed. American Public Health Association, Washington DC, USA.

2. Batie, C.J., LaHaie, E., Ballou, D.P., 1987. Purification and characterization of phthalate oxygenase and phthalate oxygenase reductase from Pseudomonas cepacia. Journal of Biological Chemistry 262, 1510-1518. 
3. Boonyaroj, V., Chiemchaisri, C., Chiemchaisri, W., Theepharaksapan, S., Yamamoto, K., 2012a. Toxic organic micro-pollutants removal mechanisms in long-term operated membrane bioreactor treating municipal solid waste leachate. Bioresource Technology $113,174-180$.

4. Chen, Y.X., 2003. Characterization of Phenol Biodegradation by Comamonas testosterone ZD4-1 and Pseudomonas aeruginosa ZD4-3. Biomedical and Environmental Science 16, 163-172.

5. Cheng, F., Jun, Y., Zheng, Y.G., Jiang, C.J., Hu, L.F., Wu, Y.Y., Shen, D.S., 2010. Dibutyl phthalate degradation by Enterobacter sp. T5 isolated from municipal solid waste in landfill bioreactor. International Biodeterioration and Biodegradation 64, 442-446.

6. Da, L., Tong, Z., Herbert H.P., 2007. Denitrifying degradation of dimethyl phthalate. Applied Microbiology and Biotechnology 74, 221-229.

7. Feng, Z., Kunyan, C., Xiangdong, L., Jiamo, F., Guoying, S., 2004. Biodegradation kinetics of phthalate esters by Pseudomonas fluorescens FS1. Process Biochemistry 39, 1125-1129.

8. Gitiafroz, R., 2012. Microorganisms and Metabolic Pathways Involved in Anaerobic Benzene Biodegradation under Nitrate-Reducing Conditions. Ph.D. Thesis. Chemical Engineering and Applied Chemistry. University of Toronto, CANADA (http://hdl.handle.net/1807/32720).

9. Hai, F.I., Tessmer, K., Nguyen, L.N., Kang, J., Price, W.E., Nghiem, L.D., 2011. Removal of micropollutants by membrane bioreactor under temperature variation. Journal of Membrane Science 383, 144-151.

10. Herbert, F., Dawei, L., Tong, Z., 2007. Aerobic degradation of diethyl phthalate by Sphingomonas sp. Bioresource Technology 98, 717-720. 
11. Huang, M.Z., Ma, Y.W., Wang, Y., Wan, J.Q., Zhang, H.P., 2010. The fate of di-n-butyl phthalate in a laboratory-scale anaerobic/anoxic/oxic wastewater treatment process. Bioresource Technology 101, 7767-7772.

12. Jagannath, C.K., Chandrappa, M.K., Yogesh, S., 2011. Biodegradation of Carbofuran phenol by free and immobilized cells of Klebsiella pneumonia ATCC13883T. World Journal of Microbiology and Biotechnology 27, 25-29.

13. Jiang, Y., Yang, X., Liu, B., Zhao, H., Cheng, Q., Cat, B., 2004. Catechol 2,3Dioxygenase from Pseudomonas sp. Strain ND6: Gene Sequence and Enzyme Characterization. Bioscience, Biotechnology and Biochemistry 68, 1798-1800.

14. Jiaxi, L., Ji-Dong G., 2007. Complete degradation of dimethyl isophthalate requires the biochemical cooperation between Klebsiella oxytoca $\mathrm{Sc}$ and Methylobacterium mesophilicum Sr isolated from Wetland sediment. Science of the Total Environment 380, 181-187.

15. Kalogeris, E., Sanakis, Y., Mamma, D., Christakopoulos, P., Kekos, D., Stamatis, H., 2006. Properties of catechol 1,2 dioxygenase from Pseudomoas putida immobilized in Calcium alginate hydrogels. Enzyme and Microbial Technology 39, 1113-1121.

16. Kushalatha, M., Vidya, G., Karigar, C., 2012. Biodegradation of 2-Chlorophenol by Rhodopseudomonas palustris. Bioremediation 16, 1-8.

17. Mankidy, R., Wiseman, S., Ma, H., Giesy, J.P., 2013. Biological impact of phthalates. Toxicology Letters 217, 50-58.

18. Marrot, B., Barrios-Martinez, A., Moulin, P., Roche, N., 2006. Biodegradation of high phenol concentration by activated sludge in an immersed membrane bioreactor. Biochemical Engineering 30, 174-183. 
19. Peerzada, K., Chand, R., Rajinder, P., Sarojini, J., Vijeshwer, V., Khurshid, I.A., Ghulam, N.Q., 2006. A novel esterase from Bacillus subtilis (RRL 1789): Purification and characterization of the enzyme. Protein Expression and Purification 45, 262-268.

20. Quan, C.S., Liu, Q., Tian, W.J., Kikuchi, J., Fan, S.D., 2005. Biodegradation of an endocrine-disrupting chemical, di-2-ethylhexyl phthalate, by Bacillus subtilis No.66. Applied Microbiology and Biotechnology 66, 702-710.

21. Rehdorf, J., Behrens, G.A., Nguyen, G.S., Kourist, R., Bornscheuer, U.T., 2012. Pseudomonas putida esterase contains a GGG(A)X-motif conferring activity for the kinetic resolution of tertiary alcohols. Applied Microbiology and Biotechnology 93, 1119-1126.

22. Scott, A.Y., Alian, G., James, A.G., Frank, F.W., Jan E.L., 1995. Rice Cationic Peroxidase Accumulates in Xylem Vessel during Incompatible Interactions with Xanthomonas oryzae pv oryzae. Plant Physiology 107, 1333-1341.

23. Shaw, S.Y., Chen, Y.J., Ou, J.J., Ho, L., 2006. Preparation and characterization of Pseudomonas putida esterase immobilized on magnetic nanoparticles. Enzyme and Microbial Technology 39, 1089-1095.

24. Slack, R.J., Gronow, J.R., Voulvoulis, N., 2005. Household hazardous waste in municipal landfills: contaminants in leachate. Science of the Total Environment 337, 119-137.

25. Stanishlauskiene, R., Rudenkov, M., Karvelis, L., Gasparaviciute, R., Meskiene, R., Casaite, V., Meskys, R., 2011. Analysis of phthalate degradation operon from Arthrobacter sp. 68b. Biologija 57, 45-54.

26. Tadkaew, N., Sivakumar, M., Khan, S.J., McDonald, J.A., Nghiem, L.D., 2010. Effect of mixed liquor $\mathrm{pH}$ on the removal of trace organic contaminants in a membrane bioreactor. Bioresource Technology 101, 1494-1500. 
27. Tadkaew, N., Hai, F.I., McDonald, J.A., Khan, S.J., Nghiem, L.D., 2011. Removal of trace organics by MBR treatment: The role of molecular properties. Water Research 45, 2439-2451.

28. Vamsee K.C., Phale P.S., 2008. Bacterial degradation of phthalate isomers and their esters. Indian Journal of Microbiology 48, 19-34.

29. Watanabe, K., Hino, S., Onodera, K., Kajie, S., Takahashi, N., 1996. Diversity in kinetics of bacterial phenol-oxyenating activity. Journal of Fermentation and Bioengineering 81, 560-563.

30. Watanabe, K., Teramoto, M., Futamata, H., Harayama, S., 1998. Molecular detection, isolation, and physiological characterization of functionally dominant phenol-degrading bacteria in activated sludge. Applied and Environmental Microbiology 64, 4396-4402.

31. Wijekoon, K.C., Hai, F.I., Kang, J., Price, W.E., Guo, W., Ngo,. H.H., Nghiem, L.D., 2013. The fate of pharmaceuticals, steroid hormones, phytoestrogens, UV-filters and pesticides during MBR treatment. Bioresource Technology 144, 247-254.

32. Xiang, X., Li, H.B., Gu, J.D., 2007. Metabolism and biochemical pathway of n-butyl benzyl phthalate by Pseudomonas fluorescens B-1 isolated from a mangrove sediment. Ecotoxicology and Environmental Safety 68, 379-385.

33. Xueling, W., Yangyang, W., Renxing, L., Qinyun, D., Decai, J., Weiliang, C., 2011. Biodegradation of an endocrine-disrupting chemical di-n-butyl phthalate by newly isolated Agrobacterium sp. and the biochemical pathway. Process Biochemistry 46, 10901094.

34. Yun, S.H., Yun, C.Y., Kim, S.I., 2004. Characterization of Protocatechuate 4,5Dioxygenase Induced from p-Hydroxybenzoate-Cultured Pseudomonas sp. K82. The Journal of Microbiology 42, 152-155. 
35. Zhang, X., Gao, P., Chao, Q., Wang, L., Senior, E., Zhao, L., 2004. Microdiversity of phenol hydroxylase genes among phenol-degrading isolates of Alcaligenes sp. from an activated sludge syste 
Table 1

Leachate characteristic and treatment performance of MBR

\begin{tabular}{ccccc}
\hline Parameters & Unit & Influent & Effluent MBR 1 & Effluent MBR 2 \\
\hline \multirow{2}{*}{ BOD } & $\mathrm{mg} / \mathrm{l}$ & $3,074 \pm 234$ & $5.0 \pm 10$ & $16 \pm 9$ \\
& & & $(99.8 \%)$ & $(99.5 \%)$ \\
$\mathrm{COD}$ & $\mathrm{mg} / \mathrm{l}$ & $6,469 \pm 473$ & $131 \pm 97$ & $234 \pm 32$ \\
& & & $(98.0 \%)$ & $(96.4 \%)$ \\
$\mathrm{TOC}$ & $\mathrm{mg} / \mathrm{l}$ & $1,856 \pm 110$ & $29 \pm 53$ & $38 \pm 42$ \\
& & & $(98.5 \%)$ & $(98.0 \%)$ \\
$\mathrm{TN}$ & $\mathrm{mg} / \mathrm{l}$ & $205 \pm 29$ & $30.6 \pm 48$ & $33.5 \pm 41$ \\
& & & $(85.1 \%)$ & $(83.7 \%)$ \\
$\mathrm{TKN}$ & $\mathrm{mg} / \mathrm{l}$ & $109 \pm 40$ & $18.0 \pm 28$ & $20.7 \pm 14$ \\
& & & $(83.5 \%)$ & $(81.0 \%)$ \\
$\mathrm{NH} \mathrm{H}_{3} \mathrm{~N}$ & $\mathrm{mg} / \mathrm{l}$ & $51 \pm 15$ & $0.7 \pm 0.5$ & $0.7 \pm 0.3$ \\
& & & $(98.6 \%)$ & $(98.6 \%)$ \\
$\mathrm{TP}$ & $\mathrm{mg} / \mathrm{l}$ & $14 \pm 3$ & $2.2 \pm 0.4$ & $2.2 \pm 0.6$ \\
& & & $(84.6 \%)$ & $(84.6 \%)$ \\
\hline
\end{tabular}

Remark: No. of sample $=47$ 
Table 2

Micro-pollutant concentrations in influent, MLSS, waste sludge and effluent of MBR

\begin{tabular}{|c|c|c|c|c|c|c|c|}
\hline \multirow[t]{2}{*}{ Compounds } & \multicolumn{3}{|c|}{$\begin{array}{c}\text { MBR 1 } \\
\text { Concentration }(\mu \mathrm{g} / \mathrm{l})^{\dagger}\end{array}$} & \multicolumn{4}{|c|}{$\begin{array}{c}\text { MBR 2 } \\
\text { Concentration }(\mu \mathrm{g} / \mathrm{l})^{\dagger}\end{array}$} \\
\hline & Inf. & MLSS & Eff. & Inf. & MLSS & $\begin{array}{l}\text { waste } \\
\text { sludge }\end{array}$ & Eff. \\
\hline \multirow[t]{2}{*}{ BPA } & 1,015 (114) & $0(0)$ & $2(2)$ & 1,015 (114) & $0(0)$ & $0(0)$ & $3(2)$ \\
\hline & $100 \%$ & $0 \%$ & $0.2 \%$ & $100 \%$ & $0 \%$ & $0 \%$ & $0.30 \%$ \\
\hline \multirow[t]{2}{*}{ 2,6-DTBP } & 963 (163) & $0(0)$ & $11(4)$ & 963 (163) & $0(0)$ & $0(0)$ & $12(5)$ \\
\hline & $100 \%$ & $0 \%$ & $0.1 \%$ & $100 \%$ & $0 \%$ & $0 \%$ & $1.2 \%$ \\
\hline \multirow[t]{2}{*}{ BHT } & $1,006(86)$ & 58 (17) & $7(3)$ & $1,006(86)$ & $25(7)$ & $16(8)$ & $10(3)$ \\
\hline & $100 \%$ & $5.8 \%$ & $0.7 \%$ & $100 \%$ & $3.0 \%$ & $2.0 \%$ & $1.0 \%$ \\
\hline \multirow[t]{2}{*}{ DCP } & 887 (152) & $0(0)$ & $2(3)$ & 887 (152) & $0(0)$ & $0(0)$ & $5(5)$ \\
\hline & $100 \%$ & $0 \%$ & $0.2 \%$ & $100 \%$ & $0 \%$ & $0 \%$ & $0.6 \%$ \\
\hline \multirow[t]{2}{*}{ DEP } & $958(74)$ & $0(0)$ & $3(2)$ & $958(74)$ & $0(0)$ & $0(0)$ & $5(3)$ \\
\hline & $100 \%$ & $0 \%$ & $0.3 \%$ & $100 \%$ & $0 \%$ & $0 \%$ & $0.5 \%$ \\
\hline \multirow[t]{2}{*}{ DBP } & 1,087 (120) & $103(54)$ & $5(2)$ & 1,087 (120) & $25(8)$ & $21(11)$ & $5(3)$ \\
\hline & $100 \%$ & $9.5 \%$ & $0.5 \%$ & $100 \%$ & $2.30 \%$ & $1.9 \%$ & $0.5 \%$ \\
\hline \multirow[t]{2}{*}{ DEHP } & 804 (182) & 609 (126) & $7(4)$ & 804 (182) & 209 (73) & 235 (92) & $15(4)$ \\
\hline & $100 \%$ & $75.7 \%$ & $0.9 \%$ & $100 \%$ & $26.0 \%$ & $29.2 \%$ & $1.9 \%$ \\
\hline \multirow[t]{2}{*}{$\mathrm{BBzP}$} & $1,003(95)$ & $71(50)$ & $6(4)$ & $1,003(95)$ & 33 (14) & 24 (27) & $9(8)$ \\
\hline & $100 \%$ & $7.1 \%$ & $0.6 \%$ & $100 \%$ & $3.3 \%$ & $2.4 \%$ & $0.9 \%$ \\
\hline
\end{tabular}

${ }^{\dagger}$ Average value (SD), No. of samples $=58$ 
Table 3

Biodegradation capacities of micro-pollutants of MBR sludge at day 0 and day 519.

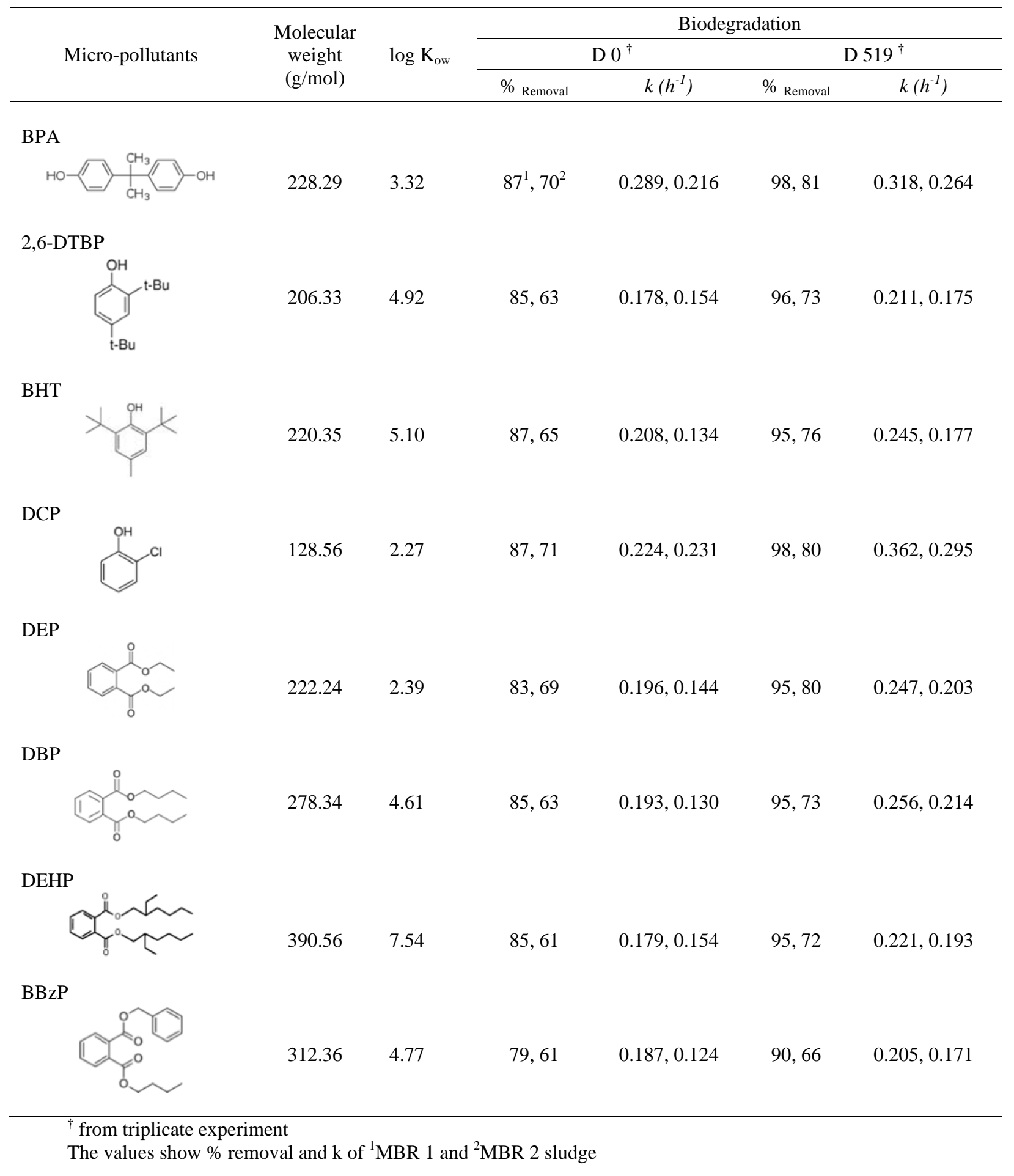



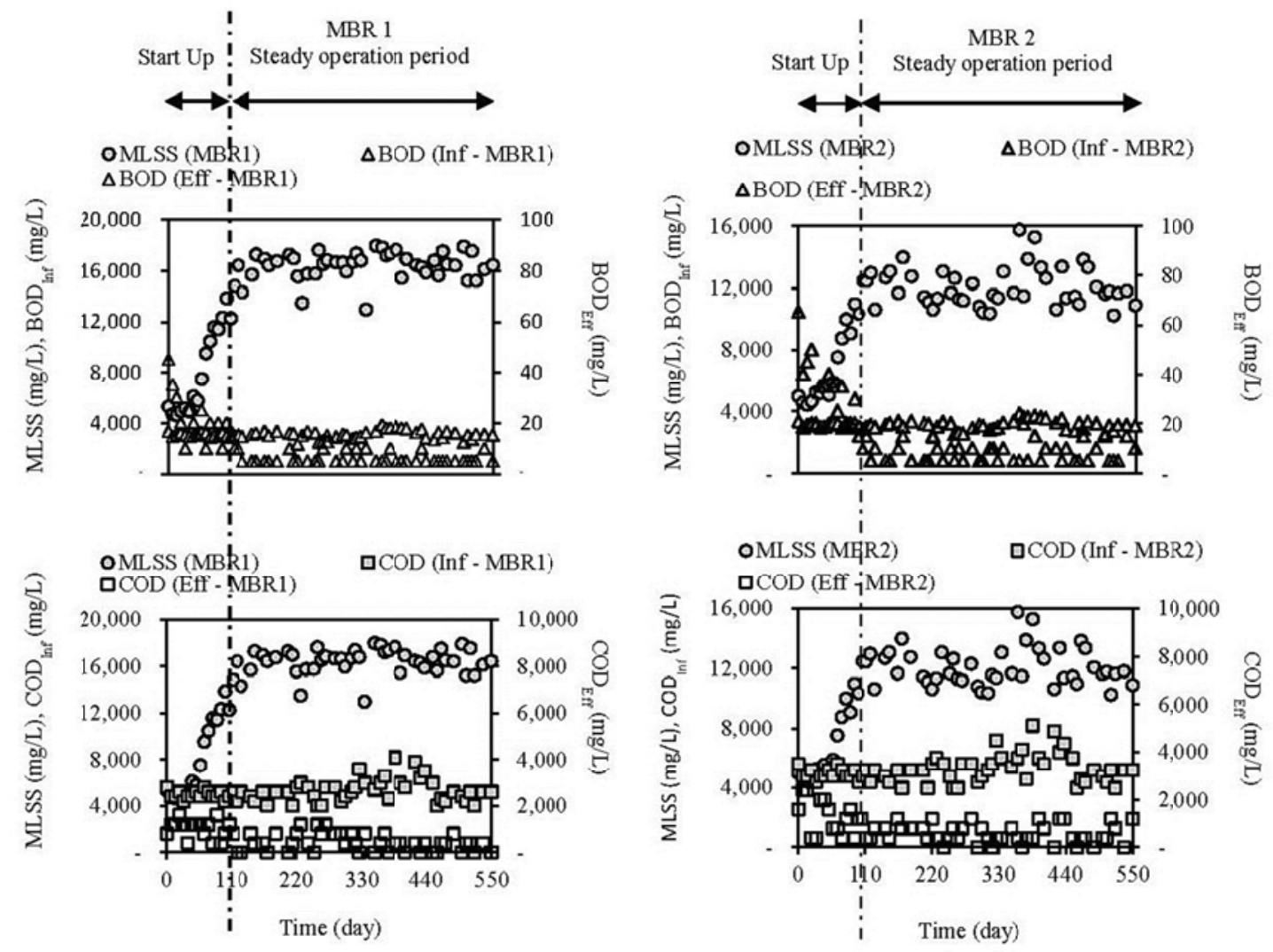

Fig. 1. Influent BOD, COD and MLSS concentrations in MBR1 and MBR2 


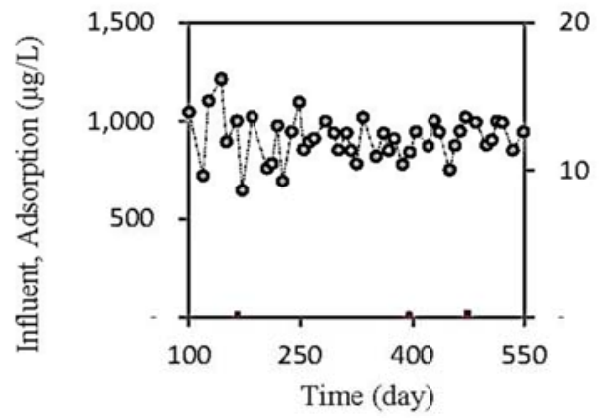

(a)

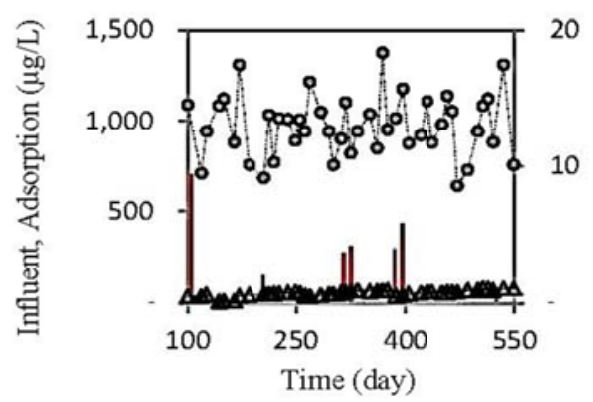

(c)

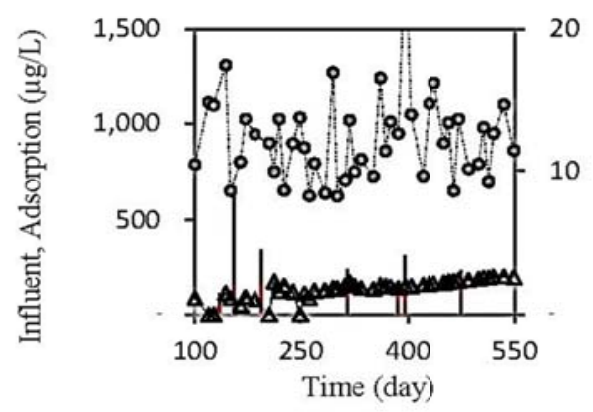

(e)

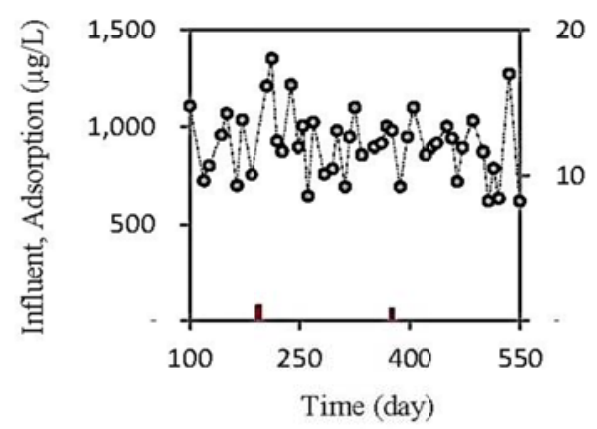

(g)

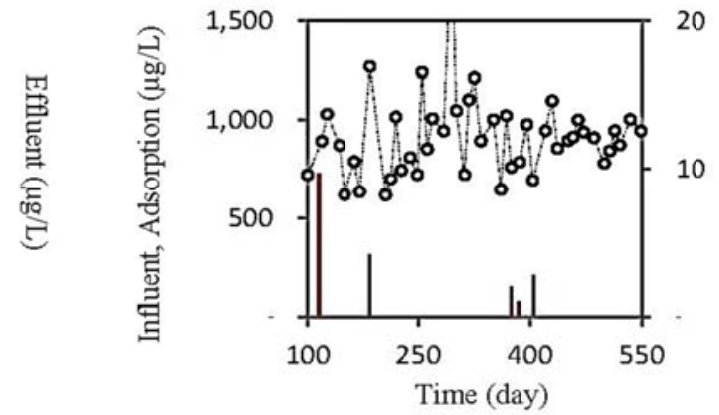

(b)

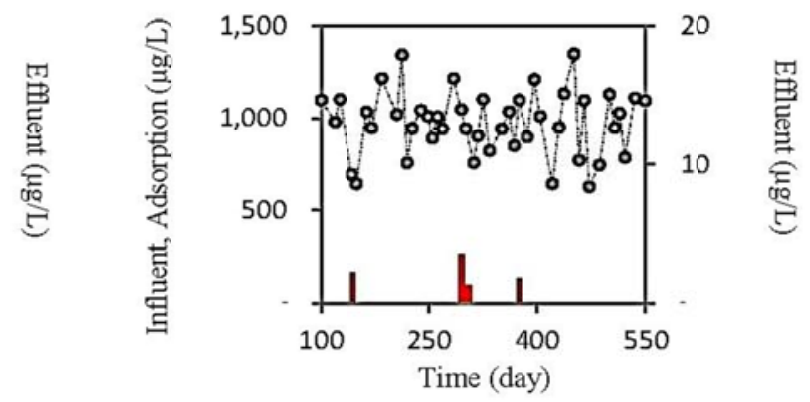

(d)

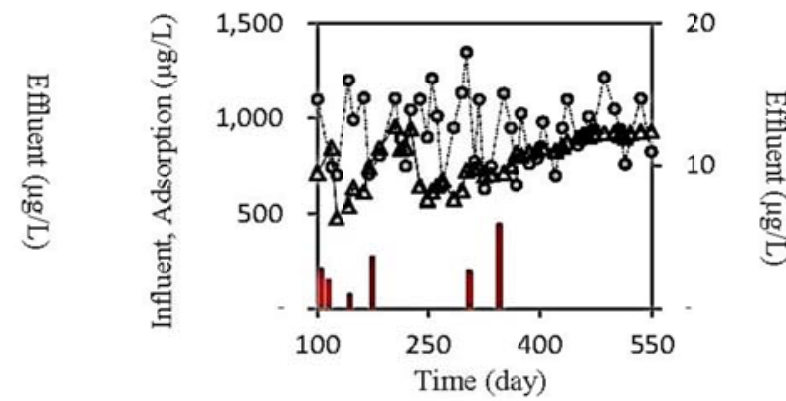

(f)

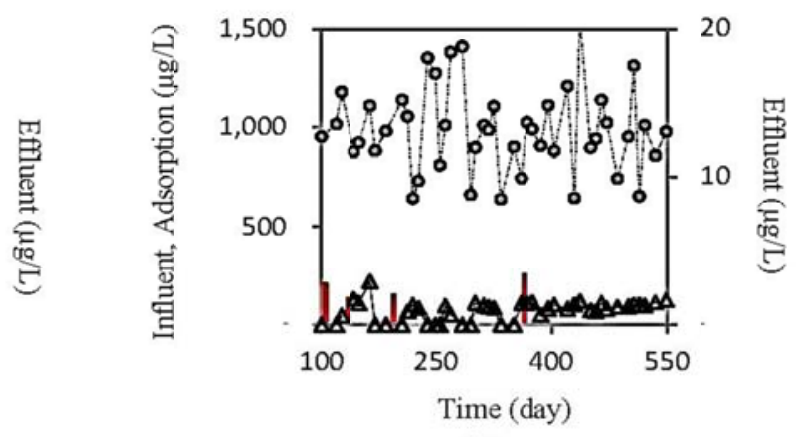

(h)

Fig. 2. Variations of micro-pollutants concentrations in MBR 1 (a) BPA (b) 2,6 DTBP (c) BHT (d) DEP (e) DBP (f) DEHP (g) DCP and (h) BBzP 


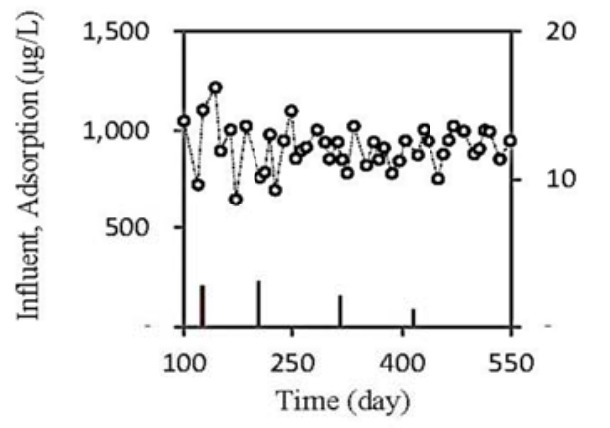

(a)

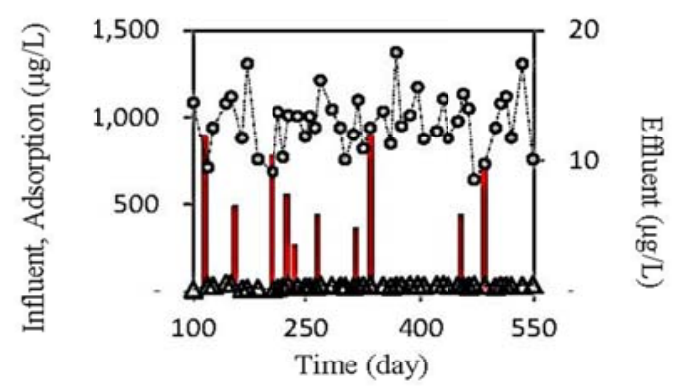

(c)

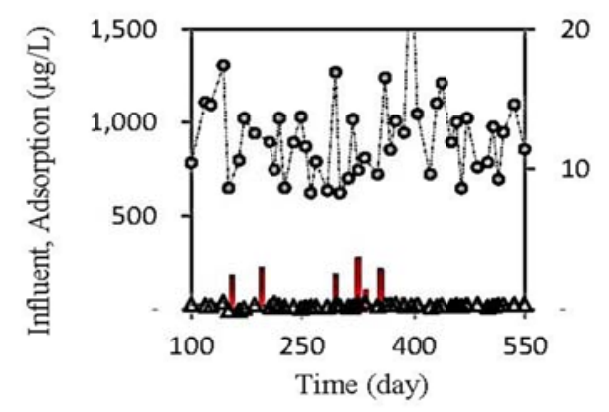

(e)

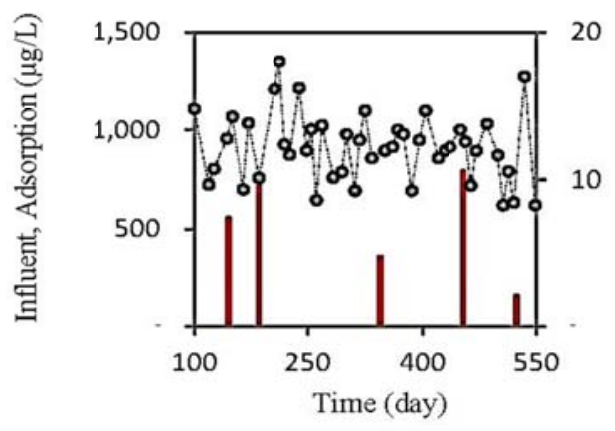

(g)

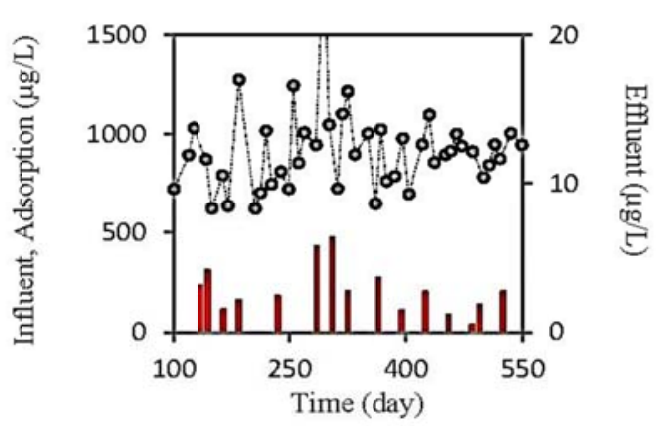

(b)

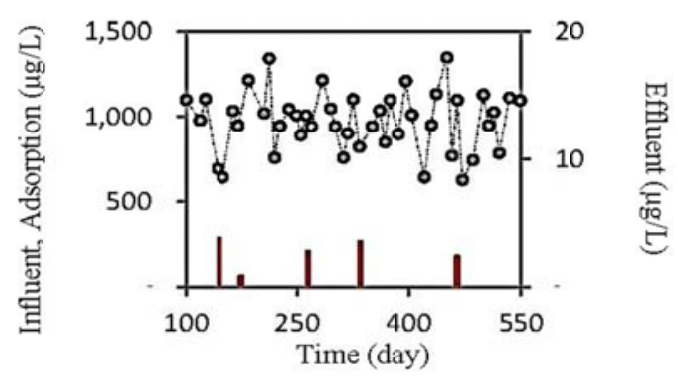

(d)

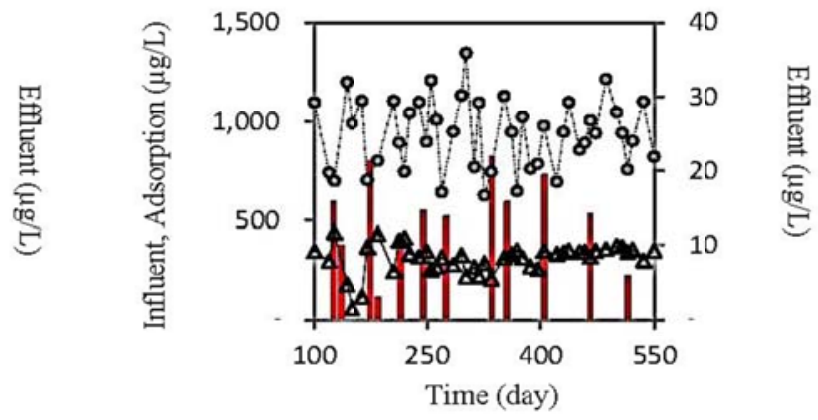

(f)

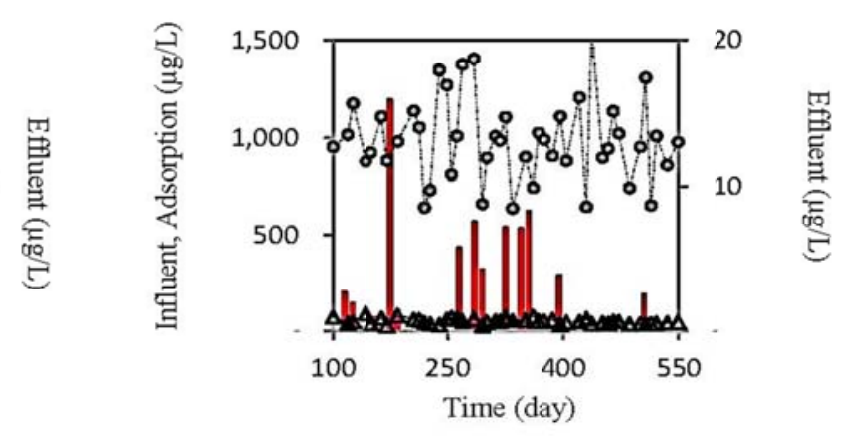

(h)

Fig. 3. Variation of micro-pollutant concentrations in MBR 2 (a) BPA (b) 2,6 DTBP (c) BHT (d) DEP (e) DBP (f) DEHP (g) DCP and (h) BBzP -. - - influent effluent $\quad---\triangle--\cdot$ adsorption onto sludge 


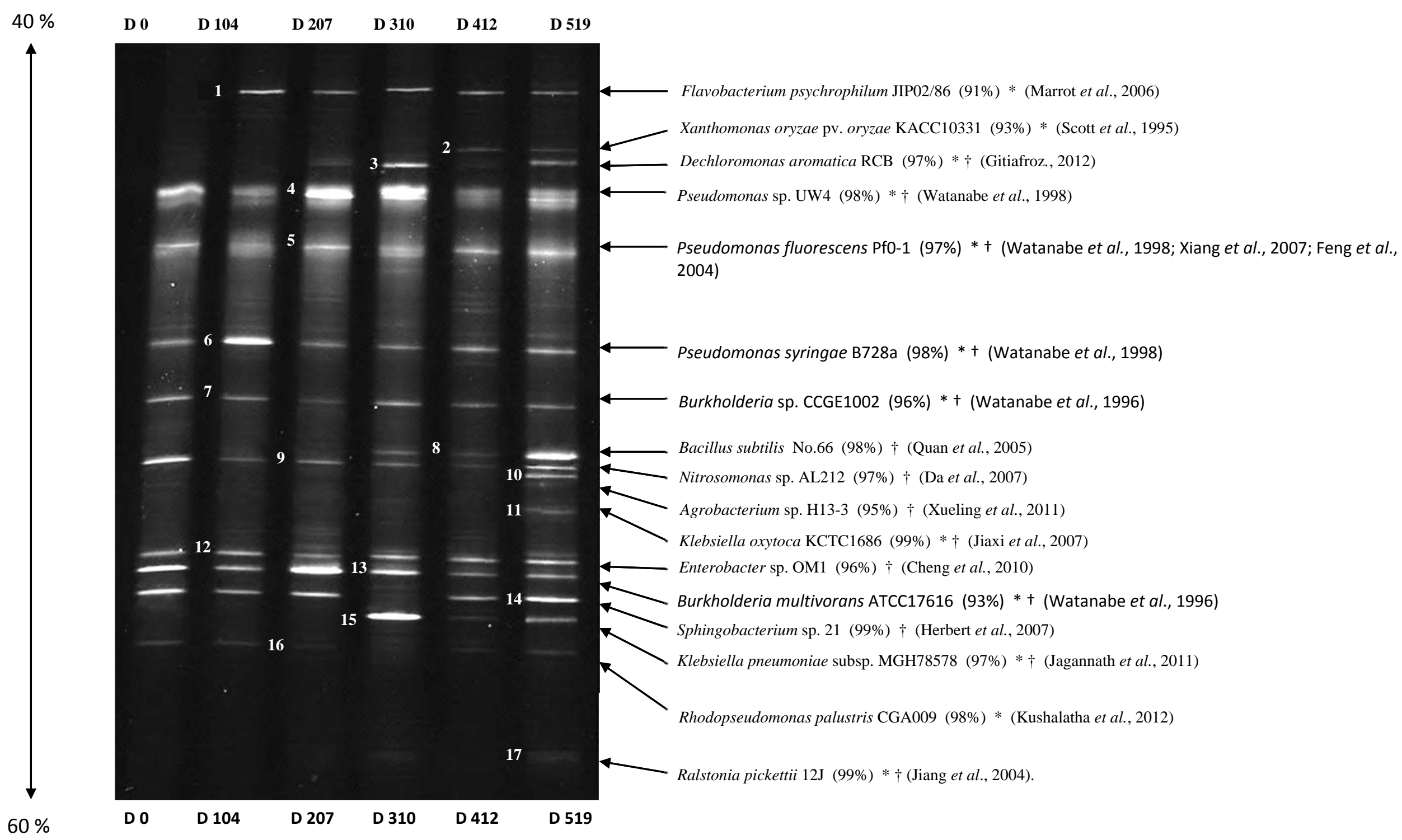

Fig. 4. DGGE profile of PCR amplification of MBR 1 samples on day 0, 104, 207, 310, 412 and 519. 


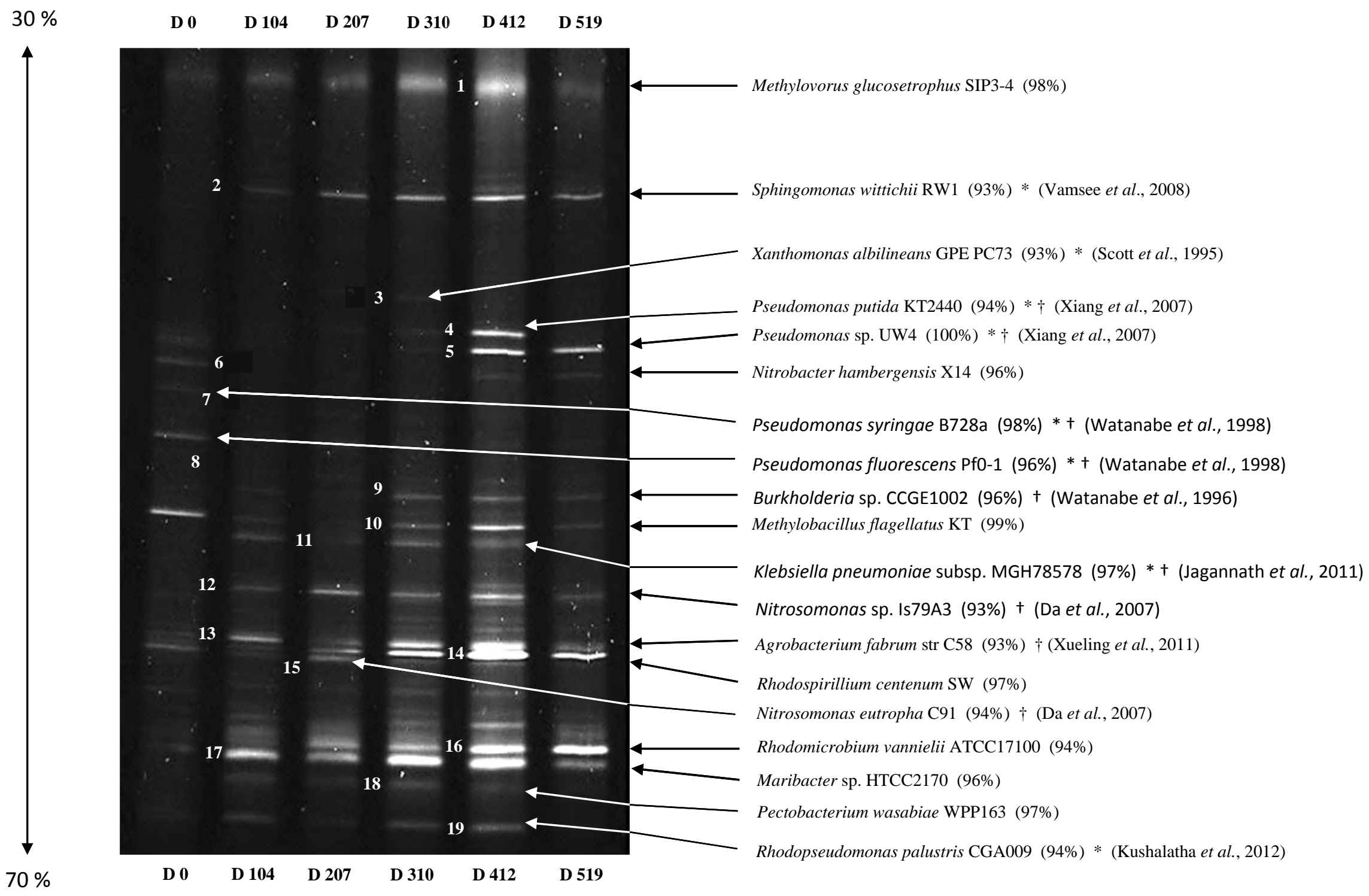

Fig. 5. DGGE profile of PCR amplification of MBR 2 samples on day 0, 104, 207, 310, 412 and 519 